
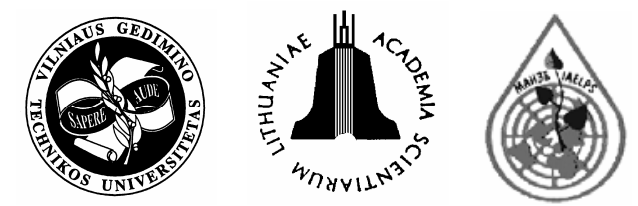

\title{
ESTIMATION OF VIBRATION IN KLAIPE்DA POWDERY MANURE DISCHARGE TERMINAL
}

\author{
Raimondas Grubliauskas ${ }^{1}$, Gintas Stankus ${ }^{2}$, Vaidotas Vaišis ${ }^{3}$, Vytautas Nainys ${ }^{4}$ \\ ${ }^{1,2,3}$ Dept of Environmental Protection, Vilnius Gediminas Technical University, \\ Saulètekio al. 11, LT-10223 Vilnius, Lithuania. \\ E-mail:1'raimon@ap.vtu.lt; ${ }^{2}$ gintass@ap.vtu.lt; ${ }^{3}$ vaisisv@ap.vtu.lt; \\ ${ }^{4}$ Dept of Labour Safety and Fire Protection, Vilnius Gediminas Technical University, \\ Sauletekio al. 11, LT-10223 Vilnius, Lithuania.E-mail: ${ }^{4}$ vytautas.nainys@st.vtu.lt
}

Submitted 6 Mar 2006; accepted 18 May 2006

\begin{abstract}
In contemporary life the mechanization of industrial and agricultural production, increasing traffic flows in towns and settlements, and modernization of household technologies result in the expansion of vibration and noise areas. This is in particular experienced by the industrial enterprise staff, vehicle drivers, passengers and others. Vibration affects the nervous system, blood circulation, tissues and does other kinds of harm to human health. The impact on humans depends on a distance to a vibration source, material whereby vibration spreads, and the duration and velocity of vibration. The spread of vibration together with noise significantly increases the impact of vibration.

Noise and vibration problems are encountered in seaport discharge terminals as well. The investigation of vibration in the bulk fertilizer terminal of Klaipeda Stevedoring Company as well as obtained findings were compared to permissible values specified in the Lithuanian Hygiene Norms. The investigation showed the highest vibration acceleration levels inside the terminal, where they varied from 0,4 to $3,2 \mathrm{~m} / \mathrm{s}^{2}$, and outdoors, by the fertilizer discharge terminal, on the paving, where they varied from 0,0005 to $0,0042 \mathrm{~m} / \mathrm{s}^{2}$ (at $1-16 \mathrm{~Hz}$ frequency).
\end{abstract}

Keywords: vibration, vibration acceleration, vibration equipment, discharge terminal, vibration levels.

\section{Introduction}

Body vibration is very intensive in macine building, technological processes, construction and other fields. Attempts are made to avoid the harm of vibration and a resonance effect in equipment being developed as well as buildings and constructions when vibration is employed to carry out various technological processes, develop and operate new vibratory machines etc [1].

Harmful vibration often causes direct danger to important installations, machinery and parts thereof, for instance, various mechanical drives, turbines, planes, bridges and other constructions and machinery Vibration can even cause accidents of equipment. Components of moving connections also show quicker wear because of vibration.

By his touch man feels bodies vibrating at up to $8000 \mathrm{~Hz}$ frequency; however, in fact vibration in the range of $20-200 \mathrm{~Hz}$ is encountered.

Vibration affects all the areas of human skin receptors. Human body parts are most sensitive to vibration at different frequencies of vibration: the head - at around $25 \mathrm{~Hz}$, the thorax - at $60 \mathrm{~Hz}$, abdominal organs - from 4 to $8 \mathrm{~Hz}$ [2].

Harmful effect of mechanical vibration influences man's functional and physiological condition. Investiga- tions show that vibration causes general fatigue and weakness, does harm to the human nervous system and arouses muscular atrophy. Those who are regularly exposed to vibration catch vibration illness. The most dangerous is the vibration of $6-9 \mathrm{~Hz}$ because it coincides with certain specific frequencies of human internal organs and may mechanically damage them [3].

Vibration can also spread via the soil. In this case, to absorb vibration, special structures are used or such distances between the focus and an object under study are maintained as not to exceed an allowable vibration level.

Vibration occurs as a result of non-balanced parts of a certain system when rotating movements or recurrent shocks are present $[4,5]$.

To speed up the process of unloading bulk mineral fertilizers from railway cars as well as under difficult product discharge conditions (e $\mathrm{g}$ in case fertilizers are packed or stuck to a wall in a car) pneumatic vibratory discharge equipment Junets is used at Klaipėda Stevedoring Company. Two dischargers of this type are used for one railway car. They transfer the vibration energy of high-frequency pneumatic shock onto a car body, in this way ensuring a better powdery condition of the products discharged.

The whole transhipment process is mechanized and automated (Fig 1). 

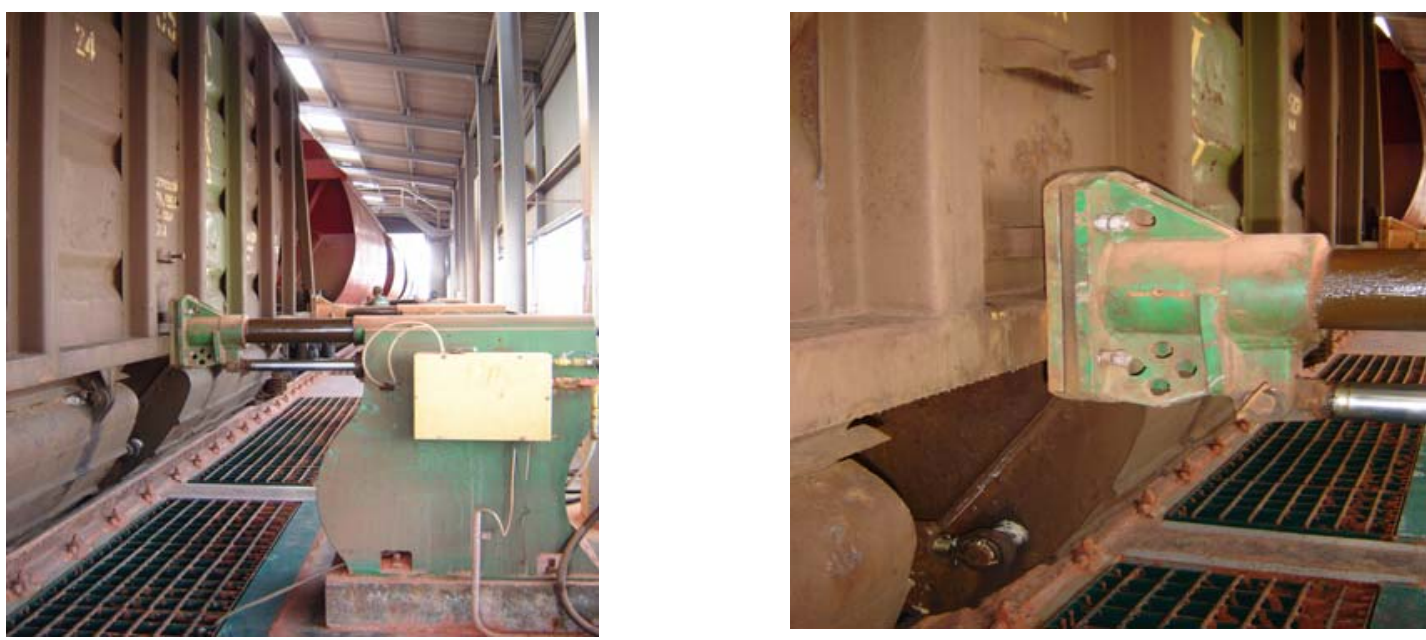

Fig 1. Equipment causing vibration of railway car walls
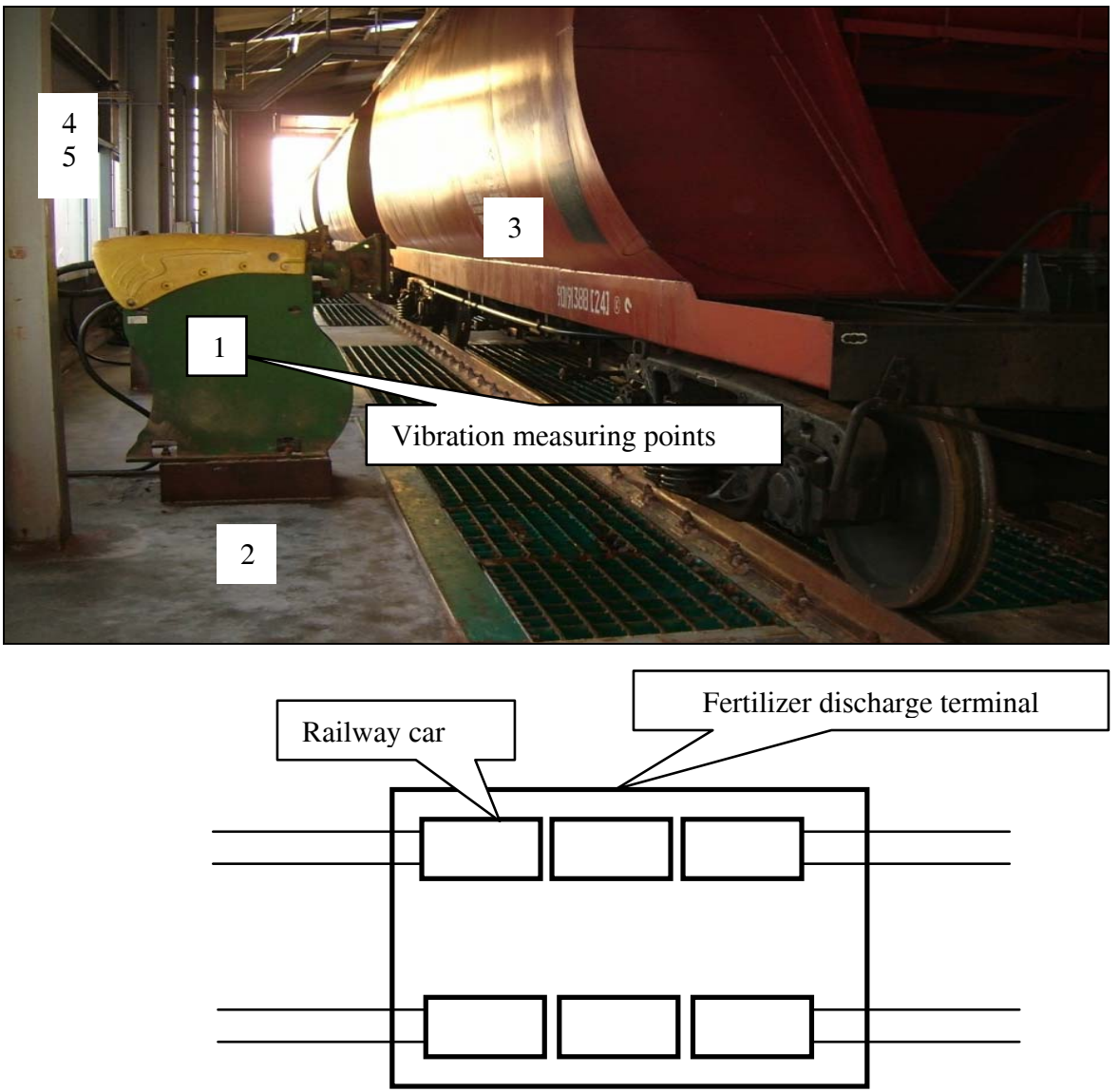

6
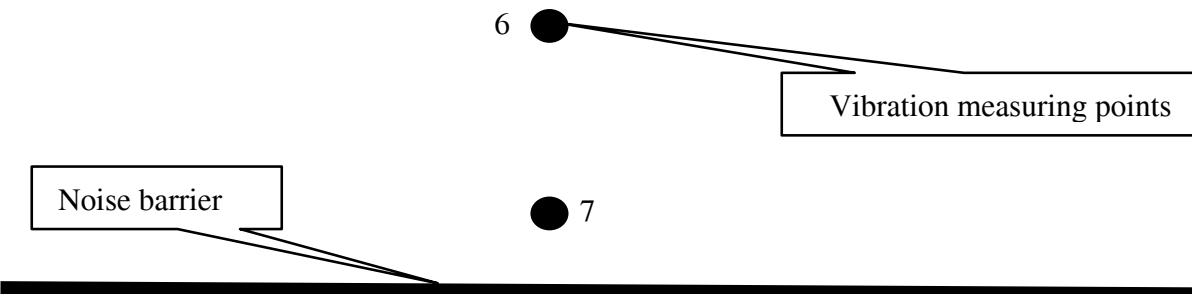

Fig 2. Vibration measuring points in bulk fertilizer discharge terminal: a - general view of measuring point allocation; $b$ - layout scheme of vibration measuring points near bulk fertilizer discharge terminal: 1 - on body of vibratory equipment Junets; 2 - near vibratory equipment Junets, on pavement; 3 - on car wall; 4 - inside terminal, on building wall; 5 - outdoors, on exterior building wall; 6 - outdoors on pavement (at $2 \mathrm{~m}$ distance from building); 7 - outdoors on pavement (at $20 \mathrm{~m}$ distance from building) 
By impacting car walls, vibratory equipment causes impulsive noise and shock vibration. At the time of shock, a part of its energy transforms into vibro-acoustic energy [6].

Intensive sound and air as well as soil vibration caused by its waves are harmful to buildings, flora and fauna and, what is the most important, to man himself $[7,8]$.

The core aim of this investigation is to estimate vibration in the bulk fertilizer terminal and compare received findings with permissible vibration acceleration values specified by the Lithuanian Hygiene Norms.

\section{Investigation methods}

The velocity and acceleration of vibration and their levels are measured by using vibration metering systems which consist of a sensor, an amplifier, filters and an indicator. The frequency range cannot be smaller than 1$100 \mathrm{~Hz}$.

Noise and vibration meters VŠV-003-M2 and Bruel\&Kjaer mediator 2260 are used to measure vibration. A relative measuring error of $\mathrm{VS} \mathrm{V}-003-\mathrm{M} 2$ device is $\pm 2,5 \%$, and it records vibration from $1 \mathrm{~Hz}$ to $18 \mathrm{kHz}$. This device can measure the values and levels of vibration velocity and acceleration. A relative measuring error of Bruel\&Kjaer mediator 2260 is $\pm 1,5 \%$.

The character of vibration is determined prior to making measurements. To set the characteristic of vibration time, the dynamics parameter switch of the device is set at an indication "slowly", and the change of the parameter being recorded has to be observed for not shorter period than 1 minute.

The sensor of vibration measuring is fastened with a magnet. When measurements are made on sites with a hard pavement, the sensor is fastened directly on hard surfaces.

Upon having selected measuring points, vibration is recorded at three points allocated at a $1,5 \mathrm{~m}$ distance from one other in the places of the highest vibration.

Vibration measuring points are shown in Fig 2.

Places selected for the measurements of vibration acceleration level are allocated inside the bulk fertilizer discharge terminal and around it.
The measuring system is calibrated before and after vibration measurements according to corresponding instructions. If calibration results show bigger difference than 1,1 time, vibration measurements are repeated.

\section{Investigation findings}

Vibration in the bulk fertilizer discharge terminal was measured with the aim of estimating the level and spread of vibration caused by various technological processes.

Characteristic places were selected for vibration measurements in the fertilizer discharge terminal. Measurements were taken on the body of a pneumatic vibratory discharge equipment and near it on the pavement, on the wall of a railway car and on the building wall of the bulk fertilizer discharge terminal. The aim is to study vibration impacting a terminal worker in his workplace. In order to estimate the spread of vibration caused during various technological processes, measurements were performed outdoors at a $2 \mathrm{~m}$ and $10 \mathrm{~m}$ distance from the building of the fertilizer discharge terminal. ble.

The values of measured vibrations are given in Ta-

Fig 3 presents vibration measurements performed inside the bulk fertilizer discharge terminal. Here vibration level in octave frequencies is separated.

The data given in the Table and Fig 3 show that the highest vibration acceleration level $\left(0,4-3,2 \mathrm{~m} / \mathrm{s}^{2}\right)$ was recorded near the vibratory equipment, i e in the workplace of an unloading equipment operator. At the presence of higher frequencies $(31,5$ and $63 \mathrm{~Hz})$ the highest vibration level was recorded on the car wall, and reached 3,2 and $7,0 \mathrm{~m} / \mathrm{s}^{2}$, respectively. The lowest level of vibration in the measuring area was recorded on the interior wall of the bulk fertilizer discharge terminal.

Fig 4 shows vibration acceleration level on the pavement inside the discharge terminal and outdoors on the pavement, at a 2 and $10 \mathrm{~m}$ distance from the wall of the discharge terminal. Vibration acceleration level in separate octave frequencies is also separate here.

Measurement results of vibration acceleration level

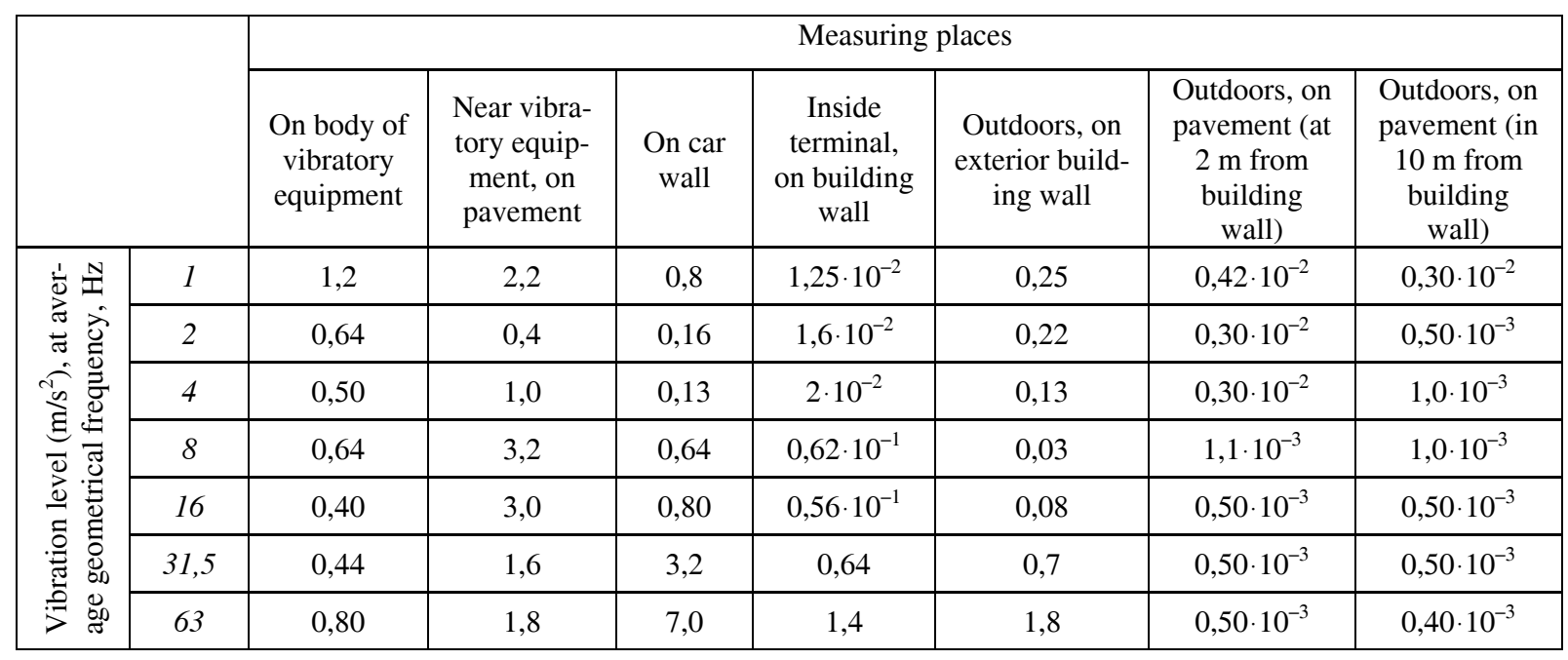




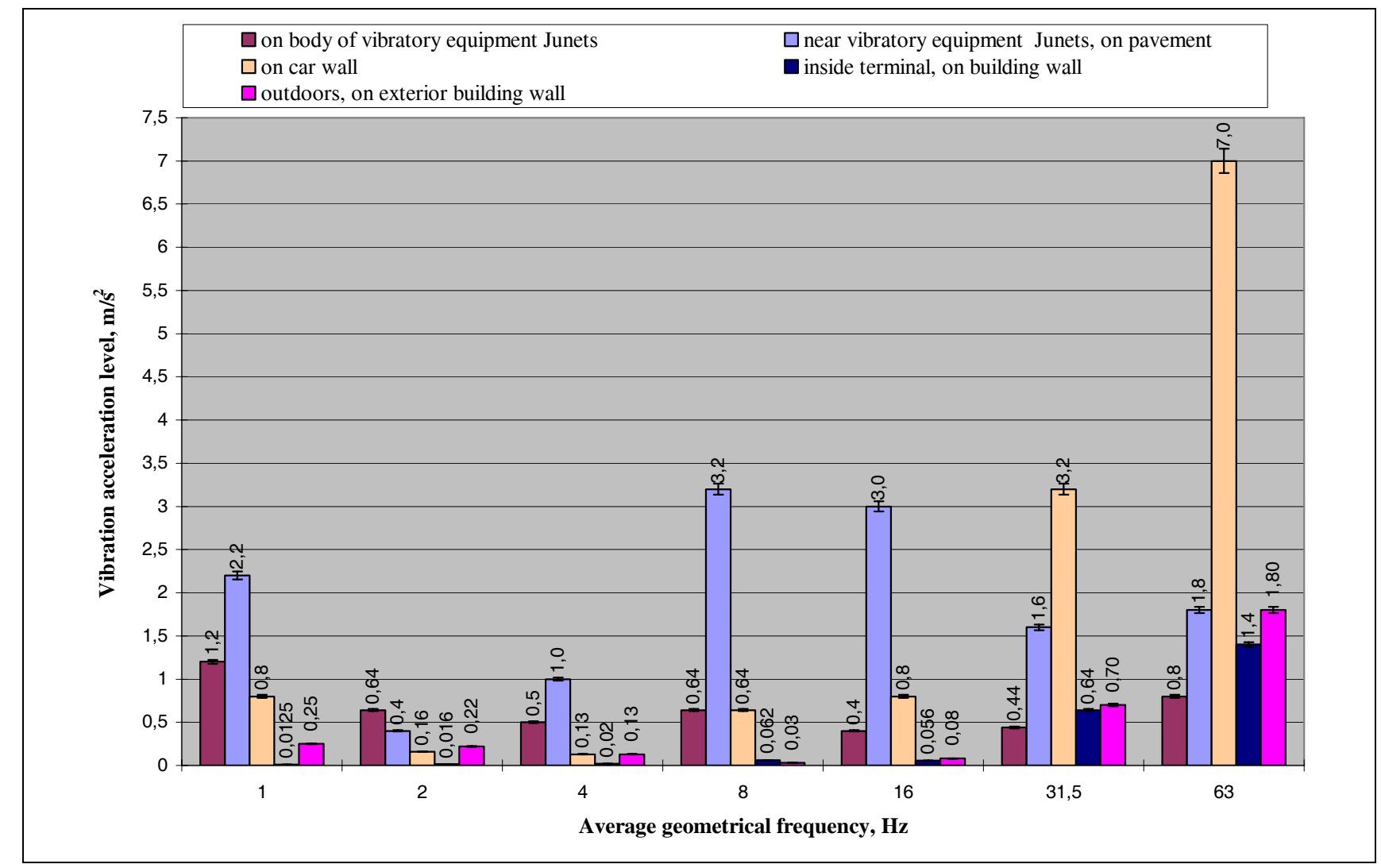

Fig 3. Measurements of vibration acceleration level in bulk fertilizer discharge terminal

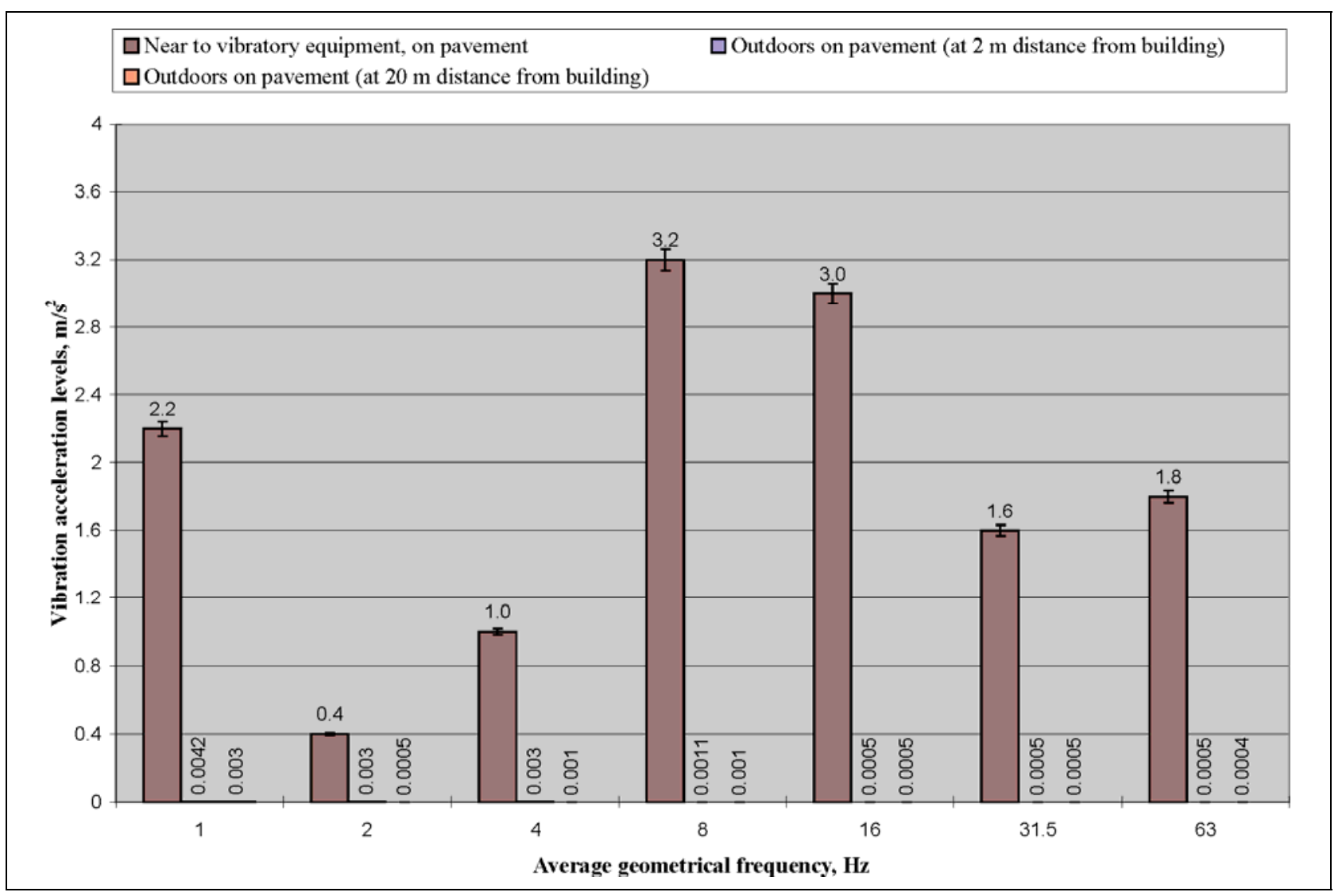

Fig 4. Vibration spread in the bulk fertilizer discharge terminal 
Fig 4 shows that a higher level of vibration acceleration was recorded inside the bulk fertilizer discharge terminal than outside it. In frequency octaves vibration acceleration level inside the terminal vary within the range of 0,4 and $3,2 \mathrm{~m} / \mathrm{s}^{2}$, in the meantime outside, near the fertilizer discharge terminal, they are from 0,0005 to $0,0042 \mathrm{~m} / \mathrm{s}^{2}$. This is preconditioned by the structures of terminal foundation which suppresses the transfer of vibrations from inside the terminal to the environment. It can also be stated that as the distance from the fertilizer discharge terminal increases, the energy of vibrations weakens, and the recorded vibration level at a $2 \mathrm{~m}$ distance from the terminal is several times higher compared to that in measuring places located at a $20 \mathrm{~m}$ distance.

\section{Conclusions}

1. The highest level of vibration acceleration by the direction resultant was recorded close to a vibratory equipment Junets, i e on the pavement in an operator's workplace.

2. At $1-16 \mathrm{~Hz}$ frequencies the highest level of vibration acceleration varied within the range of 0,4 to $3,2 \mathrm{~m} / \mathrm{s}^{2}$, and outside, near the bulk fertilizer discharge terminal, the level varied from 0,0005 to $0,0042 \mathrm{~m} / \mathrm{s}^{2}$.

3. At $31,5-63 \mathrm{~Hz}$ frequencies the highest level of vibration acceleration was recorded on the car wall where it varied from 3,2 to $7,0 \mathrm{~m} / \mathrm{s}^{2}$.
4. Vibration impacting humans did not exceed the permissible vibration level in all the frequency octaves.

\section{References}

1. Kaulakys, J. Physical technological pollution of the environment (Fizinè technologine aplinkos tarša). Vilnius: Technika, 1999. $99 \mathrm{p}$ (in Lithuanian).

2. Ustinavičienè, R.; Obelenis, V.; Ereminas, D. The health of the workers and the current working conditions. Medicine (Medicina), 40(9), Kaunas, 2004, p 897-904 (in Lithuanian).

3. Harris, Cyril. Shock and Vibration Handbook, 4th edition, McGraw-Hill, New York, 1995.

4. Fröhner, K. D.; Li, Z. Evaluating improved illumination of railroad yards. Environmental Engineering (Aplinkos inžinerija), Vol VI, No 2. Vilnius: Technika, 1998, p 48-52.

5. Merkevičius, S.; Deikus, J. Acoustic Pollution of LightDuty Wheeled Tractors. Environmental Engineering (Aplinkos inžinerija), Vol VI, No 1. Vilnius: Technika, 1998, p 37-43.

6. Vethecan, J. K.; Subic, A. Measures of Location Effectiveness of Vibration Absorbers. International Journal of Acoustics and Vibration, Vol VII, No 3, September 2002, p 7-13.

7. Fröhner, K. D.; Li, Z. Reliable design of illumination in railroad yards. Environmental Engineering (Aplinkos inžinerija), No 1(5). Vilnius: Technika, 1996, p 5-10.

8. Crocke, M. J. Recent Developments in Acoustics and Vibration. The International Refereed Journal, Vol IV, No 1, March 1999, p 17-25.

\title{
VIBRACIJOS VERTINIMAS KLAIPĖDOS BIRIŲJŲ TRĄŠŲ IŠKROVIMO TERMINALE
}

\author{
R. Grubliauskas, G. Stankus, V. Vaišis, V. Nainys
}

Santrauka

Nūdienos gyvenime, mechanizavus pramonès ir žemès ūkio gamyba, didejjant transporto srautams miestuose ir gyvenvietėse, modernejjant buitinei technikai, sparčiai didejja vibracijos bei triukšmo keliamo diskomforto zonos. Ypač su tuo susiduria pramonės i̇monių darbuotojai, transporto priemonių vairuotojai, jų keleiviai ir kt. Vibracija veikia nervų sistemą, kraujo apytaka, audinius ir kitaip kenkia sveikatai. Vibracijos poveikis žmogui priklauso nuo atstumo iki jos židinio, medžiagos, kuria vibracija sklinda, vibracijos trukmès ir sklidimo spartos. Kai vibracija sklinda kartu su triukšmu, jos poveikis žymiai didesnis.

Su triukšmo bei vibracijos problemomis susiduriama ir jūrų uostų kroviniu stotyse. Vibracijos tyrimai atlikti Klaipedos jūrų krovinių kompanijos biriujų trąšu terminale. Gauti rezultatai palyginti su Lietuvos higienos normose pateiktais leistinaisiais dydžiais. Tyrimu metu didžiausi vibracijos pagreičio lygiai terminalo viduje kito nuo $0,4 \mathrm{iki} 3,2 \mathrm{~m} / \mathrm{s}^{2}$, o lauke, prie trąšų iškrovimo terminalo, ant grindinio, - nuo 0,0005 iki $0,0042 \mathrm{~m} / \mathrm{s}^{2}$ (esant 1-16 Hz dažniams).

Prasminiai žodžiai: vibracija, vibracijos pagreitis, vibruojantys ịrenginiai, iškrovimo terminalas, vibracijos lygiai.

\section{ОЦЕНКА ВИБРАЦИЙ В КЛАЙПЕДСКОМ ТЕРМИНАЛЕ ПО РАЗГРУЗКЕ ПОРОШКООБРАЗНЫХ УДОБРЕНИЙ}

\section{Р. Грубляускас, Г. Станкус, В. Вайшис, В. Найнис}

Р е $з$ юм е

В настоящее время в связи с механизацией промышленного и сельскохозяйственного производства, увеличением транспортных потоков в городах и населенных пунктах, а также совершенствованием бытовой техники из-за вызываемого ими шума и вибраций быстрыми темпами увеличиваются дискомфортные зоны. Особенно часто в таких зонах приходится находиться работникам промышленных предприятий, водителям транспортных средств, их пассажирам и др. Вибрация отрицательно сказывается на здоровье человека: его нервной системе, кровообращении, тканях. Воздействие вибрации на человека зависит от расстояния до ее источника, материала, по которому распространяется вибрация, продолжительности и частоты распространения вибрации. В случае, когда вибрация распространяется вместе с шумом, ее воздействие увеличивается. 
C проблемами шума и вибрации сталкиваются также работники станций по разгрузке грузов в морских портах. Исследование вибраций проводилось в терминале по разгрузке порошкообразных удобрений в Клайпедской компании морских грузов. Полученные результаты сравнены с величинами, допустимыми литовскими гигиеническими нормами. Во время исследований наибольшие уровни скоростей вибраций внутри терминала колебались от $0,4 \mathrm{~m} / \mathrm{c}^{2}$ до $3,2 \mathrm{~m} / \mathrm{c}^{2}$, а на открытом месте выгрузки удобрений - от $0,0005 \mathrm{~m} / \mathrm{c}^{2}$ до $0,0042 \mathrm{~m} / \mathrm{c}^{2}$ (при частоте 1-16 герц).

Ключевые слова: вибрация, ускорение вибрации, вибрирующие установки, терминал по разгрузке, уровни вибрации.

Raimondas GRUBLIAUSKAS. Master, doctoral student, Dept of Environmental Protection, Vilnius Gediminas Technical University (VGTU).

Master of Science (environmental engineering) (2005). Bachelor of Science (environmental engineering) (2003), VGTU. Publications: author of 3 scientific publications. Research interests: environmental protection, noise prevention.

Gintas STANKUS. Master, Dept of Environmental Protection, Vilnius Gediminas Technical University (VGTU).

Master of Science (environmental engineering), VGTU, 2005. Bachelor of Science (environmental engineering), Lithuanian University of Agriculture, 2003. Publications: author of 3 scientific publications. Research interests: environmental protection, ionizing radiation.

Vaidotas VAIŠIS. Doctor of Technological Sciences, Dept of Environmental Protection, (VGTU).

Master of Science (environmental engineering), 2001. Bachelor of Science (environmental engineering), VGTU, 1999. Publications: author of 13 scientific publications. Research interests: environmental protection, noise prevention, sorbents of oil products.

Vytautas NAINYS. Dr, Dept of Labour Safety and Fire Protection, Vilnius Gediminas Technical University (VGTU).

Master of Science (forestry), Moscow, 1965. First degree in Mechanical Engineering, Lithuanian University of Agriculture, 1956. Publications: author of 61 scientific publications, 1 handbook, 3 patents, 2 methodological books. Research interests: labour safety, human safety, environmental protection, acoustics. 